\title{
Original Research \\ Physicians' generic drug prescribing behavior in district hospitals: a case of Phitsanulok, Thailand
}

\author{
Pinyupa PLIANBANGCHANG, Kanchalee JETIYANON, Charawee SUTTALOUNG, Lalida KHUMCHUEN.
} Received (first version): 7-Apr-2010 Accepted: 1-Jul-2010

\begin{abstract}
${ }^{*}$
Generic prescribing is a sound approach to contain health care costs. However, little is known about physicians' prescribing patterns in the Thai context. Objective: To explore physicians' generic prescription patterns in district hospitals. Methods: Data was collected from three of the eight district hospitals between January and December 2008 (final response rate $37.5 \%$ ). All participating hospitals were between 30 and 60 -bed capacity. The researchers reviewed $10 \%$ of total outpatient prescriptions in each hospital.

Results: A total of 14,500 prescriptions were evaluated. The majority of patients were under universal health coverage $(4,367 ; 30.1 \%)$, followed by senior citizens' health insurance $(2,734 ; 18.9 \%)$, and civil servant medical benefit schemes $(2,419$; $16.7 \%)$. Ten thousand six hundred and seventy-one prescriptions (73.6\% of total prescriptions) had at least one medication. Among these, each prescription contained $2.85(\mathrm{SD}=1.69)$ items. The majority of prescriptions $(7,886 ; 73.9 \%)$ were prescribed by generic name only. Drugs prescribed by brand names varied in their pharmacological actions. They represented both innovator and branded-generic items. Interestingly, a large number of them were fixed-dose combination drugs. All brand name prescriptions were off patented. In addition, none of the brand-name drugs prescribed were categorized as narrow therapeutic range or any other drug that had been reported to have had problems with generic substitution.

Conclusion: The majority of prescriptions in this sample were written by generic names. There is room for improvement in brand name prescribing patterns.
\end{abstract}

Keywords: Drugs, Generic. Drug Prescriptions. Thailand.

\footnotetext{
"Pinyupa PLIANBANGCHANG. PhD, Associate Professor, Faculty of Pharmaceutical Sciences, Naresuan University. Phitsanulok (Thailand).

Kanchalee JETIYANON. PhD, Associate Professor,

Faculty of Agriculture, Natural Resources and

Environment, Naresuan University. Phitsanulok (Thailand).

Charawee SUTTALOUNG. PharmD student, Faculty of

Pharmaceutical Sciences, Naresuan University.

Phitsanulok (Thailand).

Lalida KHUMCHUEN. PharmD student, Faculty of

Pharmaceutical Sciences, Naresuan University.

Phitsanulok (Thailand).
}

\section{COMPORTAMIENTO DE LOS MÉDICOS EN PRESCRIPCIÓN DE GENÉRICOS EN HOSPITALES DISTRITALES: EL CASO DE PHITSANULOK, TAILANDIA}

\section{RESUMEN}

La prescripción genérica es algo que podría contener los costes sanitarios. Sin embargo, se sabe poco de los hábitos de prescripción genérica de los médicos tailandeses.

Objetivo. Explorar los hábitos de prescripción genérica de los médicos en hospitales distritales. Métodos. Se recogieron datos de tres de los ocho hospitales de distrito entre enero y diciembre de 2008 (tasa final de respuesta 37,5\%). Todos los hospitales participantes estaban entre 30 y 60 camas de capacidad. Los investigadores revisaron el $10 \%$ del total de las prescripciones ambulatorias de cada hospital.

Resultados. Se evaluó un total de 14500

prescripciones. La mayoría de los pacientes estaban bajo la cobertura sanitaria universal $(4367 ; 30,1 \%)$ seguidos del seguro de ciudadanos mayores (2734; $18,9 \%$ ) y de los sistemas de funcionarios civiles (2419; 16,7\%). 10671 prescripciones $(73,6 \%$ del total de prescripciones) tenían al menos un medicamento. Entre estas, cada prescripción contenía 2,85 (DE=1,69) ítems. La mayoría de las prescripciones $(7886 ; 73,9 \%)$ estaban escritas en nombre genérico solamente. Los medicamentos prescritos por marca comercial variaban en sus acciones farmacológicas. Estos representaban tanto ítems innovadores como genéricos con marca. Curiosamente, un gran número de ellos eran combinaciones a dosis fijas. Todas las prescripciones por marca eran medicamentos con patente caducada. Además, ninguna de las marcas prescritas estaba calificada de estrecho margen terapéutico u otros medicamentos que hayan comunicado problemas con la sustitución genérica. Conclusión. La mayoría de las prescripciones en esta muestra estaban escritas en nombres genéricos. Existe espacio para mejorar los patrones de prescripción por marcas.

Palabras clave: Medicamentos genéricos. Prescripción de medicamentos. Tailandia. 


\section{INTRODUCTION}

The Thai health expenditure has steadily skyrocketed for the past decades. ${ }^{1,2}$ Pharmaceutical items accounted for a large portion of such costs. In 2005, Thai people consumed 103,517 million THB worth of drugs in wholesale prices (approximately US $\$ 2,958$ million), or 186,331 million THB in retail prices (approximately US $\$ 5,324$ million). ${ }^{1}$ This accounted for almost $43 \%$ of the total health expenditures, or $2.63 \%$ of national GDP.

To contain this escalating cost, the use of generic drugs was widely encouraged due to their relatively low price compared to innovator items. ${ }^{3,4}$ If implemented, the strategy would prove to substantially save cost in many health care settings. ${ }^{5,6}$ Unfortunately, the reports solely focused the economic outcome from the perspective of administrators. Other studies mainly concentrated on the cognitive and affective aspects such as beliefs and attitudes towards generic drug use and generic substitution. ${ }^{7-9}$ Little is known about the actual prescribing behaviors of physicians in the Thai context. For this reason, this study was conducted to explore physicians' prescribing behavior in outpatient departments of district hospitals in Phitsanulok, Thailand. More specifically, the investigators were interested to learn about the physicians' generic and brand name prescribing patterns. The information obtained from this study would be useful as a feedback to improve generic prescribing in the province.

\section{METHODS}

This descriptive study retrospectively reviewed prescriptions from outpatient departments between January 1 and December 31, 2008. Selfadministered questionnaires soliciting hospital background information such as hospital capacity, average number of patients in the out-patient department, and drug procurement system, were sent to directors of eight district hospitals in Phitsanulok along with cover letters explaining the details of the study and a consent form declaring hospital permission for the investigators to collect prescription data. If the director agreed to participate in this study, he or she would pass on the questionnaire and consent form to the head of the pharmacy department to fill out. Once the investigator received the returned questionnaire and consent form, a contact was made to set up a time and means to retrieve data on prescriptions. The study protocol was approved by Naresuan University Ethics Committee (Project Code 510101 0042).

The investigators sorted prescriptions by date, and systematically sampled $10 \%$ of total outpatient department prescriptions dated between January 1 and December 31, 2008 from each hospital. Descriptive statistics such as mean, standard deviation, and percentage, were employed to answer the stated research questions.

\section{RESULTS}

\section{Background Information}

Of the eight hospitals contacted, five consented to participate in this study. When further contacted, two did not have the data in the format that could be processed. That is, one discarded all prescriptions every three months. The other two nested prescriptions within patients' profiles. They could not be re-arranged and retrieved by date. For this reason, prescriptions from three hospitals were analyzed.

All three participating hospitals were between 30 and 60 beds in capacity. The range of patients in the out-patient department during the same period was between 120-350 per day. Each hospital had a unique drug purchasing policy. One hospital used "one generic, one item" policy. Another allowed both generic and brand name drugs to be available for each generic name, depending on the physicians' request. The other purchased only the generic version, if available on the market.

During fiscal year 2008 (October 1, 2007 to September 30, 2008), drugs used in chronic noncommunicable and infectious diseases shared the greatest purchasing value in all hospitals. The majority of these items were acquired by their generic names (Table 1). Antihypertensive and

\begin{tabular}{|c|c|c|c|}
\hline Rank & Hosnital A & & \\
\hline 1 & HM Mixtard ${ }^{(11} 70 / 30$ (B/I) & & \\
\hline & & & Metformin $500 \mathrm{mg}$ tab (G) \\
\hline 2 & Metformin $500 \mathrm{mg}$ tab (G) & Amlodipine 5 mg tab (G) & GPO-Vir $^{(85}(\mathrm{B} / \mathrm{l})$ \\
\hline 3 & Glibenclamide $5 \mathrm{mg}$ tab (G) & Metformin $500 \mathrm{mg} \mathrm{tab}(\mathrm{G})$ & HM Mixtard $^{(21}$ 70/30 (B/l) \\
\hline 4 & Berodual $^{(82} \mathrm{MDI}(\mathrm{B} / \mathrm{l})$ & Propanolol $10 \mathrm{mg}$ tab $(\mathrm{G})$ & Amlodipine $5 \mathrm{mg}$ tab (G) \\
\hline 5 & Amoxycillin 500 mg cap (G) & Methylsalicylate balm (G) & Amoxycillin $500 \mathrm{mg}$ cap (G) \\
\hline 6 & Cef- $3^{\circledR 3}$ injection (B/G) & 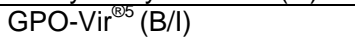 & Glibenclamide $5 \mathrm{mg}(\mathrm{G})$ \\
\hline 7 & $\begin{array}{l}\text { Aluminium hydroxide suspension } \\
\text { (G) }\end{array}$ & Amoxycillin $250 \mathrm{mg}$ cap (G) & Simvastatin $20 \mathrm{mg}$ tab (G) \\
\hline 8 & Simvastatin $20 \mathrm{mg}$ tab (G) & Amoxycillin $500 \mathrm{mg}$ cap (G) & Berodual $^{(82} \mathrm{MDI}(\mathrm{B} / \mathrm{l})$ \\
\hline 9 & Clenil $^{(84} \mathrm{MDI}(\mathrm{B} / \mathrm{l})$ & Glibenclamide $5 \mathrm{mg}$ tab $(\mathrm{G})$ & Analgesic cream (G) \\
\hline 10 & NPH Insulin (G) & Simvastatin $20 \mathrm{mg}$ tab (G) & $\begin{array}{l}0.9 \% \text { Sodium chloride sterile } \\
\text { solution } 1,000 \mathrm{ml}(\mathrm{G})\end{array}$ \\
\hline \multicolumn{4}{|c|}{$\begin{array}{l}\text { Note: (B/l) Brand name-Innovator; (BG) Brand name-Generic; (G) Generic name; }{ }^{1} \text { Human premixed insulin }(30 \% \\
\text { soluble insulin \& } 70 \% \text { NPH insulin, Novo Nordisk; }{ }^{2} \text { Ipratopium Br } 0.02 \mathrm{mg} \& \text { fenoterol } 0.05 \mathrm{mg} \text {, Boehringer Ingelheim; }{ }^{3}{ }^{3} \text { Ceftriaxone disodium, Siam Pharmceutical; }{ }^{4} \text { Beclomethasone dipropionate } 50 \mathrm{mcg} \text {, Chiesi; }{ }^{5} \text { Nevirapine } 200 \mathrm{mg} \& \\
\text { lamivudine } 150 \mathrm{mg} \& \text { stavudine } 30 \mathrm{mg} \text {, Government Pharmaceutical Organization }\end{array}$} \\
\hline
\end{tabular}


hypoglycemic drugs were found to be the most frequently prescribed during the fiscal year, followed by antibiotics, and antiasthmatic drugs (Table 2).

\begin{tabular}{|l|c|c|c|}
\hline \multicolumn{4}{|l|}{$\begin{array}{l}\text { Table 2. Top ten pharmaceutical categories prescribed in } \\
\text { each hospital in the Fiscal Year 2008 }\end{array}$} \\
\hline Drug category & $\begin{array}{c}\text { Hospital } \\
\text { A }\end{array}$ & $\begin{array}{c}\text { Hospital } \\
\text { B }\end{array}$ & $\begin{array}{c}\text { Hospital } \\
\text { C }\end{array}$ \\
\hline $\begin{array}{l}\text { Antihypertensive } \\
\text { drugs }\end{array}$ & 5 & 1 & 1 \\
\hline $\begin{array}{l}\text { Oral hypoglycemic } \\
\text { drugs }\end{array}$ & 1 & 2 & 2 \\
\hline Antimicrobial drugs & 4 & 3 & 3 \\
\hline Cardiovascular drugs & 2 & 5 & 4 \\
\hline Antiasthmatic drugs & 3 & 4 & 5 \\
\hline Antiepileptic drugs & 6 & 6 & 7 \\
\hline Vaccines and serum & 8 & 7 & 6 \\
\hline Life saving drugs & 7 & 8 & 9 \\
\hline Anesthetics & 9 & 9 & 8 \\
\hline Antineoplastic drugs & 10 & 10 & 10 \\
\hline
\end{tabular}

\section{Out-patient Prescriptions Review}

After sorting prescriptions by date, the investigators systematically sampled $10 \%$ of the total prescriptions from each hospital, resulting in 14,500 prescriptions to be reviewed.

The majority of patients were insured by the government universal health coverage (4,367; $30.1 \%$ ), followed by senior citizen health coverage $(2,734 ; 18.9 \%)$, and civil servant medical benefit schemes $(2,419 ; 16.7 \%)$ (Table 3). From all prescriptions, $10,671(73.6 \%)$ had at least one pharmaceutical item. The rest $(3,829 ; 26.4 \%)$ did not contain any item for different reasons (Table 4), the majority of which was not indicated. The three most frequently mentioned reasons for issuing prescriptions without drugs were as follows: Patients coming for wound dressing $(516,13.5 \%)$; Patients asking for medical certificates (512, $13.4 \%$ ); and Patients being referred to Thai traditional massage department $(440,11.5 \%)$.
$22.5 \%$ ) were found to use both generic and trade names for different items in the same prescription.

The most frequently prescribed drugs by generic names were analgesics, followed by antibiotics, and non-steriodal anti-inflammatory drugs (Table 5). Paracetamol was the most prescribed drugs by generic name, followed by amoxicillin, diclofenac, analgesic balm, aspirin, vitamin B 1-6-12, diphenhydramine, bromhexine, enalapril, and propanolol. Table 6 indicates ten of the most frequently prescribed drugs by brand names. Norgesic $\AA$, a fixed dose combination muscle relaxant and analgesic formula was the first in the list. This medication alone accounted for $1.4 \%$ of total items in this review. This was followed by Diclocil $\AA$, Losec $\AA$, Motilium $\AA$, Tramol $\AA$, Atarax $\AA$, Actifed $\AA$, Bisolvon $\AA$, Ranidine $\AA$, and Brufen $\AA$. Note that brand name items composed of both innovator and brand generic items.

Interestingly, fixed dose combination drugs, i.e., pharmaceutical items containing more than one active ingredient, made up a sizeable portion of drugs prescribed by brand names. That is, combination drugs were found in $803(28.8 \%)$ of prescriptions written by brand names (data not shown).

\section{DISCUSSION}

This retrospective study revealed actual prescribing patterns in three district hospitals. The study design had an advantage of not imposing any influence on physicians' behavior. Overall, the rate of generic prescribing was high and compliant with the 1993 National Drug Policy which encouraged the use of generic drugs. ${ }^{10}$

This finding, however, must be interpreted with caution since the sample was all primary care settings. The hospital formularies were limited,

\begin{tabular}{|c|c|c|c|}
\hline \multirow[b]{2}{*}{ Insurance scheme } & \multicolumn{3}{|c|}{ Number prescriptions (\%) } \\
\hline & $\begin{array}{c}\text { Total } \\
(\mathrm{N}=14,500)\end{array}$ & $\begin{array}{l}\text { With at least } \\
\text { one drug* } \\
(n=10,671)\end{array}$ & $\begin{array}{l}\text { Without drug* } \\
(n=3,829)\end{array}$ \\
\hline Universal health coverage & $4,367(30.1)$ & $3,273(75.0)$ & $1,094(25.0)$ \\
\hline Senior citizens & $2,734(18.9)$ & $2,268(82.9)$ & $466(17.1)$ \\
\hline Civil servant medical benefit & $2,419(16.7)$ & $1,307(54.0)$ & $1112(46.0)$ \\
\hline Infant and child aged $0-12$ coverage & $1,939(13.4)$ & $1,483(76.5)$ & $455(23.5)$ \\
\hline Low incomes & $774(5.3)$ & $683(88.2)$ & $91(11.8)$ \\
\hline Social security & 499 (3.4) & $265(53.1)$ & 234 (46.9) \\
\hline Disabled & 474 (3.3) & $417(88.0)$ & $57(12.0)$ \\
\hline Health volunteers & $451(3.1)$ & $316(70.0)$ & $135(30.0)$ \\
\hline Students, grade 7-9 & $329(2.3)$ & $287(87.2)$ & $42(12.8)$ \\
\hline Vehicle accident coverage & $199(1.4)$ & $132(66.3)$ & 67 (33.7) \\
\hline Veterans & $182(1.3)$ & $144(79.1)$ & $38(20.9)$ \\
\hline Community leaders & $60(0.4)$ & $51(85.0)$ & $9(15.0)$ \\
\hline Priests & $47(0.3)$ & $45(95.7)$ & $2(4.3)$ \\
\hline Not identified & $26(0.2)$ & $0(0.0)$ & $26(100.0)$ \\
\hline
\end{tabular}

Among 10,670 prescriptions with at least one drug, one prescription contained an average of 2.85 items $(S D=1.69)$, or 30,412 items in total. The majority of prescriptions $(7,886 ; 73.9 \%)$ were written by generic names only. Three hundred and eighty-seven $(3.6 \%)$ used trade names only. The rest $(2,398$; mainly composed of off-patented pharmaceutical items. Further studies are warranted to explore the prescribing behavior among physicians working in secondary and tertiary care settings where investigational drugs and patented items are prevailing. However, the findings might be used to reflect physicians' prescribing patterns in small 


\begin{tabular}{|l|c|}
\hline \multicolumn{2}{|c|}{ Table 4. Reasons patients did not receive any drug in their prescriptions ( $\mathrm{n}=3,829)$} \\
\hline \multicolumn{1}{|c|}{ Reason } & Number (\%) \\
\hline Wound dressing & $516(13.5)$ \\
\hline Issuing medical certificate & $512(13.4)$ \\
\hline Referring to Thai traditional massage & $440(11.5)$ \\
\hline Counseling & $260(6.8)$ \\
\hline Referring to dental department & $233(6.1)$ \\
\hline Admission to IPD & $181(4.7)$ \\
\hline Prescribing herbal medicines & $149(3.9)$ \\
\hline Referring to another hospital & $141(3.7)$ \\
\hline Follow up & $72(1.9)$ \\
\hline Neonatal care & $49(1.3)$ \\
\hline Others (screenings, blood tests, physical examination, etc.) & $137(3.6)$ \\
\hline Not identified & $1,139(29.8)$ \\
\hline
\end{tabular}

\begin{tabular}{|l|l|c|}
\hline \multicolumn{1}{|c|}{ Table 5. Top ten most prescribed drugs by generic name } & Number* $(\%)$ \\
\hline Paracetamol & \multicolumn{1}{|c|}{ Pharmacological category } & $4,076(13.4)$ \\
\hline Amoxycillin & Analgesics & $1,468(4.8)$ \\
\hline Diclofenac & Antibiotics & $1,118(3.7)$ \\
\hline Analgesic cream & Non-steroidal anti-inflammatory drugs & $1,091(3.6)$ \\
\hline Aspirin & Topical preparations & $612(2.0)$ \\
\hline Vitamin B 1-6-12 & Non-steroidal anti-inflammatory drugs & $606(2.0)$ \\
\hline Diphenhydramine & Vitamins and minerals & $548(1.8)$ \\
\hline Bromhexine & Antihistamines & $523(1.7)$ \\
\hline Enalapril & Mucolytics & $514(1.7)$ \\
\hline Propanolol & Cardiovascular drugs & $476(1.6)$ \\
\hline Note: ${ }^{*}$ Out of total medications prescribed (n=30,412). Some prescriptions might contain more than one generic \\
\hline
\end{tabular}

\begin{tabular}{|c|c|c|c|}
\hline Trade name & Generic name & Pharmacological category & Number* $(\%)$ \\
\hline Norgesic $^{\circledR}($ iNova) & $\begin{array}{l}\text { Orphenadine citrate + } \\
\text { Paracetamol }\end{array}$ & Muscle relaxants + analgesic & $426(1.4)$ \\
\hline Diclocil $^{(}(\mathrm{BMS})$ & Dicloxacillin $\mathrm{Na}$ & Antibiotics & $283(0.9)$ \\
\hline Losec $^{\otimes}$ (AstraZeneca) & Omeprazole & Drugs use in gastrointestinal system & $141(0.5)$ \\
\hline Motilium ${ }^{\otimes}$ (Janssen-Cilag) & Domperidone & Drugs use in gastrointestinal system & $113(0.4)$ \\
\hline Tramal ${ }^{\otimes}$ (Sanofi-Aventis) & Tramadol $\mathrm{HCl}$ & Opioids & $111(0.4)$ \\
\hline $\operatorname{Atarax}^{\circledR}(\mathrm{UCB})$ & Hydroxyzine $\mathrm{HCl}$ & Antihistamines & $105(0.3)$ \\
\hline Actifed $^{\circledR}$ (GlaxoSmithKline) & $\begin{array}{l}\text { Tripolidine } \mathrm{HCl}+ \\
\text { Pseudoephedrine } \mathrm{HCl}\end{array}$ & Antihistamines & $101(0.3)$ \\
\hline $\begin{array}{l}\text { Bisolvon }{ }^{(} \text {(Boehringer } \\
\text { Ingelheim) }\end{array}$ & Bromhexine $\mathrm{HCl}$ & Mucolytics & $95(0.3)$ \\
\hline Ranidine $^{\circledR}$ (Biopharm) & Ranitidine $\mathrm{HCl}$ & Drugs use in gastrointestinal system & $87(0.3)$ \\
\hline Brufen $^{(}$(Abbott) & Ibuprofen & Non-steroidal anti-inflammatory drugs & $84(0.3)$ \\
\hline
\end{tabular}

hospitals which are the majority of health care settings in the country.

With regards to brand name prescribing, three interesting issues were identified. First, most items prescribed by brand names were off-patented, i.e., they all had their generic versions available. Furthermore, the brand names written were not necessarily innovators' items. Several branded generics were often recalled by physicians when writing their prescriptions, especially new generics. This finding, incongruence with previous studies, emphasized the influence of familiarity and brand loyalty on actual prescribing behavior, ${ }^{5,7,11}$ which, once learned, may be difficult to change. At present, all pharmaceutical items in Thailand are registered by brand names, both innovator drugs and branded generics. ${ }^{12}$ This pattern of drug registration still allows pharmaceutical companies to promote their products by brands, regardless of whether the items are already off patented. In some cases, the first generics are much more recognizable to health care practitioners than its innovators counterpart due to its much lower price. This usually made the first generic replaced its innovator in hospital formulary as soon as it was registered. To encourage generic prescribing, a generic registration policy should be developed.

Secondly, a sizable portion of drugs prescribed by brand names were fixed dose combination drug formulas. The complexity of remembering ingredients in the recipe might prompt physicians to recall only their brand names. The use of such medications, with some exceptions, hardly shows evidence of rational use of medicines. Evocations of fixed dose combination drug formulas due to harm caused by one of their active ingredients made the headlines in Thailand time and again ${ }^{13}$, leading the Thai FDA to scrutinize the registration of these formula. Elimination of such pharmaceutical items would significantly reduce brand name prescribing.

Third, some pharmaceutical items such as phynetoin, warfarin, and digoxin are narrow in their therapeutic index, so should not be substituted with generic versions without close monitoring by 
physicians. ${ }^{14}$ However, none of the brand name items were categorized as such. For this reason, there was no reason to believe that physicians were especially concerned about patients' safety when prescribing by brand names.

Even though rational use of medicines was not the aim of this study, we found that average items per prescription higher than that in developed countries. $^{15,16}$ This poly-pharmacy trend was common in the country, and might result from the availability of pharmaceutical items in the market to choose from. Since the pharmaceutical licensing in Thailand is life-long, the number of registered pharmaceutical items has long been accumulating with no systemic re-evaluation but spontaneous evocation of troubled formulas. For this reason, there currently were more than 20,000 licensed formulas. ${ }^{12}$ Since the fewer the items in the market, the more appropriate use of medicines is likely to happen, other countries have constantly been trying to review their registration lists regularly. ${ }^{17,18}$ Thailand is no exception. According to the Head of the Drug Control Department, the Thai FDA has begun its first step to systematically review all registered items in an attempt to evoke outdated, non-functional, or potentially dangerous items from the market. ${ }^{19}$

The number of medicines per prescription also reflected attitudes of physicians and patients regarding drug consumption. For many Thai people, receiving medications from the hospital signify that the problem has been taken care of. Studies found a variety of factors influencing physicians' prescribing behavior. ${ }^{20-22}$ Demand from their patients was among them. ${ }^{23}$ Given the heavy workload which always occurs in public hospitals in the country, physicians also utilized writing prescriptions as way to end the patient visit.

Some limitations of this study should be clarified. First of all, the study was small in size. A variety of factors such as demographic background of the population and hospital policies might limit its generalizability. However, there is no reason to believe that these three hospitals are different from other small hospitals in the country. In addition, the drugs prescribed were found to be in accordance with the disease burden of the country. ${ }^{1}$ Secondly, this study did not aim at evaluating prescribing appropriateness. The high rate of generic prescribing by no means indicated whether such prescriptions were rationally written. Since most studies in the past focused on economic outcome of generic prescribing, further studies are warranted to assess the appropriateness of such behavior in terms of clinical outcomes.

\section{CONCLUSIONS}

The majority of prescriptions were written by generic names. Brand name prescribing was found to be concentrated on off-patented medications. None of the items prescribed by brand name were of narrow therapeutic range. Administrative measures such as electronic prescribing system, in which all pharmaceutical items in the hospital formulary are listed in generic names only, can be utilized to enhance generic prescribing behavior.

\section{ACKNOWLEDGEMENTS}

The authors are deeply grateful for financial support from the Faculty of Pharmaceutical Sciences, Naresuan University. Sincere appreciation goes to Ms Diane Smith for her kind editorial assistance.

\section{CONFLICT OF INTEREST}

The authors declared no conflict of interest relating to conducting and publishing this research study.

This study was supported by a research grant from the Faculty of Pharmaceutical Sciences, Naresuan University.

\section{References}

1. Faramnuayphol $P$, Ekachampaka $P$, Taverat $R$, Wattanamano N. Health Services Systems in Thailand. In: Wibulpolprasert S, editor. Thailand Health Profile 2005-2007. Bangkok, Thailand: Veterans Organization of Thailand; 2007. p. 257-348.

2. Tangcharoensathien V, Harnvoravongchai P, Pittayaransarit S, Kasemsup V. Health impacts of rapid economic changes in Thailand. Soc Sci Med. 2000;51:789-807.

3. Tantivess S, Jierapong S, Jitraknatee A, Chakajnarodom S. Generic entry and drug expenditures of hospitals: case study of drugs approved by means of the new drug registration regulations. J Health Sci. 2002;11:167-176.

4. Fischer MA, Avron J. Economic consequences of underuse of generic drugs: evidence from Medicaid and implications for prescription drug benefit plan. Health Serv Res. 2003;38:1051-1063.

5. Tantivess S. Generic substitution in public and private hospitals in Thailand. J Health Sci. 2002;11:32-43.

6. Burapadaja S, Kawasaki N, Kittipongpatana O, Ogata F. Study on variation in price of prescription medicines in Thailand. Yakuga Zasshi. 2007;127:515-526.

7. Heikkila R, Mäntyselkä P, Hartikainen-Herranen K, Ahonen R. Customers' and physicians' opinions of and experiences with generic substitution during the first year in Finland. Health Policy. 2007;82:366-374.

8. Alghasham AA. Generic drug prescribing in central Saudi Arabia: perceptions and attitudes of physicians. Ann Saudi Med. 2009;29:24-29.

9. Al-Gedadi NA, Hassali MA, Shafie AA. A pilot survey on perceptions and knowledge of generic medicines among consumers in Penang, Malaysia. Pharm Pract (Internet). 2008;6(2):93-97.

10. Ministry of Public Health, Food and Drug Administration, Department of Drug Control. National Drug Policy B.E. 2536 (1993). Nonthaburi, Thailand: Ministry of Public Health; 1994. 50 p. [Transcript in Thai language] 
11. Adair RF, Holmgren LR. 2005. Do drug samples influence resident prescribing behavior? A randomized trial. Am J Med. 2005;118:881-884.

12. General information regarding drug products [Internet]. Nonthaburi, Thailand: Ministry of Public Health, Food and Drug Administration, Drug Control Department; c2009 [cited 2009 Nov 28]. Available from: http://www2.fda.moph.go.th/consumer/drug/dcenter.asp.

13. Compilation of the Ministry Orders Regarding Pharmaceutical Formula Evocation [Internet]. Nonthaburi, Thailand: Ministry of Public Health, Food and Drug Administration, Drug Control Department; c2009. [cited 2009 Nov 28]. Available from: http://wwwapp1.fda.moph.go.th/drug/zone_law/law031.asp. [Transcript in Thai language]

14. Pope ND. Generic substitution of narrow therapeutic index drugs. US Pharmacist. 2009;34 (Generic Drug Review supplement): 12-19.

15. Rokstad K, Straand J, Fugelli P. General practitioners' drug prescribing practice and diagnosis for prescribing: the Møre \& Romsdal Prescription Study. J Clin Epidemiol. 1997;50:485-494.

16. Hider P, Lay-Yee R, Davis P. Practitioners, patients, and their visits: a description of accident and medical (A\&M) clinics in New Zealand 2001/2. New Zeal Med J. 2007;120:U2538.

17. Abraham J, Lewis G. Harmonising and competing for medicines regulation: how healthy are the European Union's systems of drug approval? Soc Sci Med. 1999;48:1655-1667.

18. Hill S, Johnson K. Emerging challenges and opportunities in drug registration and regulation in developing countries. London: DFIC Health Systems Resource Center. 47 p.

19. Assavakijsiri V. 2009. The development of systematic review of drug registers in Thailand. Report presented at: The development of drug register review system; 2009 Nov 25; Bangkok, Thailand. [Transcript in Thai language]

20. Carrin G. Drug prescribing: A discussion of its variability and (ir)rationality. Health Policy. 1987;7:73-94.

21. Lambert BL, Salmon JW, Stubbings J, Gilomen-Study G, Valuck RJ, Kezlarian K. Factors associated with antibiotic prescribing in a managed care setting: an exploratory investigation. Soc Sci Med. 1997;45:1767-1779.

22. Steinman MA, Landefeld C, Gonzales R. Predictors of broad-spectrum antibiotic prescribing for acute respiratory tract infections in adult primary care. JAMA. 2003;289:719-725.

23. Stevenson FA, Greenfield SM, Jones M, Nayak A, Bradley C. GP's perceptions of patient influence on prescribing. Fam Pract. 1999;16:255-261. 